\title{
Penelitian Etnografi Komunikasi: Tipe dan Metode
}

\begin{abstract}
Kiki Zakiah
ABSTRACT

According to Hofstede, there are many approach to define culture: (1) culture as symbols; (2) culture as expressed by heroes; (3) culture as rituals; and (4) culture as a set of values. There are also many ways to investigate culture from communication perspective-ethnography of communication is one of them. Based on Lindlof and Taylor definition about ethnography of communication, this article outlined many issues from the definition of ethnography to methods, perspective and analysis unit. Ethnography of communication is a unique method of communication research that could be applied in many communication activities.
\end{abstract}

Kata kunci: etnografi komunikasi, metode, perspektif, unit analisis

\section{Pendahuluan}

Budaya yang di dalamnya terkandung ukuran, pedoman, dan petunjuk bagi kehidupan manusia, yaitu norma dan nilai yang menjadi standar berinteraksi, dibangun oleh manusia dari generasi ke generasi melalui proses komunikasi yang panjang. Nilai dan norma terlembagakan dalam kehidupan masyarakat, dipupuk dan dihargai sebagai pedoman atau kaidah bertingkah laku. Seperangkat nilai dan norma tersebut merupakan landasan fundamental bagi seseorang untuk menentukan sikapnya terhadap dunia luar.

Sebenarnya, seluruh perbendaharaan perilaku kita sangat bergantung pada budaya tempat kita dibesarkan. Konsekuensinya, budaya merupakan landasan komunikasi. bila budaya beraneka ragam, maka beraneka ragam pula praktik-praktik komunikasi.
Keragaman budaya menampakkan dirinya dalam berbagai bentuk, dari berbagai konsep yang digunakan untuk menggambarkan kebudayaan. Hofstede (1994) menyebutkan empat konsep yang secara keseluruhan dapat meng-cover berbagai manifestasi kebudayaan secara umum, yaitu: simbol-simbol, kepahlawanan, kegiatan ritual, dan nilai-nilai. Gambar memperlihatkan kedudukan konsep tersebut sebagai lapisan kulit bawang yang menunjukkan bahwa simbol-simbol merupakan lapisan terluar, sedangkan nilai-nilai merupakan lapisan terdalam, sementara kepahlawanan serta ritual berada di antaranya.

Simbol dapat berbentuk kata-kata, gerakan tangan, gambar, atau objek yang memuat makna khusus dan yang hanya dapat dipahami oleh anggota kelompok yang berada di dalam kultur bersangkutan. Kata-kata dalam bahasa atau logat tertentu bisa menunjukkan pada hal-hal seperti; 


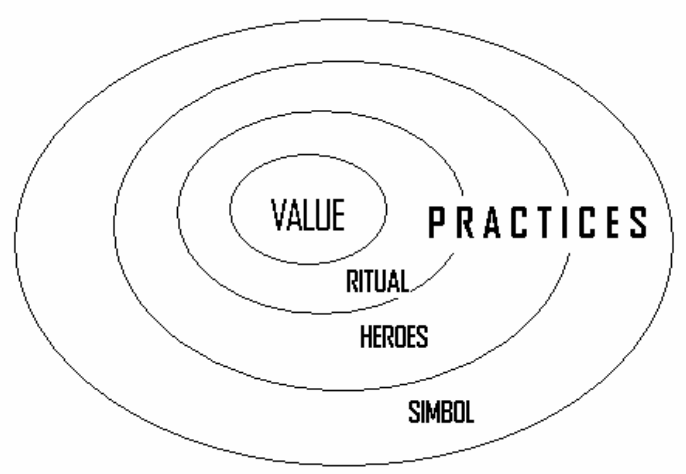

cara berpakaian, gaya rambut, coca cola, bendera, atau simbol-simbol status. Jadi, simbol-simbol yang baru bisa muncul dan berkembang, sementara simbol-simbol yang lain atau lama bisa menghilang. Simbol-simbol yang baru dari suatu kelompok kultur dapat juga ditiru oleh kelompok kultur yang lain.

Kepahlawanan biasanya menyangkut seseorang yang baik yang masih hidup maupun yang telah meninggal dunia, baik yang nyata maupun yang berupa gambaran (imajiner) saja, yang memiliki sejumlah karakteristik yang dianggap bernilai bagi kultur berangkutan dan yang kemudian juga menjadi model perilaku bagi kebanyakan anggota kultur tersebut, termasuk juga gambaran tokoh-tokoh kartun seperti Batman, atau Snoopy di AS dan Asterik di Prancis dsb yang dapat menjadi pahlawan kebudayaan. Kini pada era televisi, pilihan tokoh-tokoh kepahlawanan ini menjadi pertimbangan yang lebih penting daripada sebelumnya.

Ritual merupakan aktivitas kolektif, secara teknis tampak seperti mengada-ada di dalam mencapai tujuan yang diinginkan. Namun, dalam kultur, aktivitas ini memliki fungsi sosial yang dianggap penting dan harus mereka lakukan demi kepentingan kultur bersangkutan.

Unsur-unsur simbol, kepahlawanan, dan ritual ini dalam bentuk praktiknya sehari-hari dapat dilihat secara jelas, bahkan oleh pengamat luar. Namun, makna kulturnya tidak demikian. Ia relatif tidak terlihat dan maknanya hanya bisa dipahami secara jelas oleh orang dalam kultur bersangkutan.
Hal yang dimaksud adalah nilai yang menjadi inti kebudayaan.

Nilai merupakan tendensi-tendensi yang bersifat luas, yaitu untuk lebih menyukai keadaan atau hal hal tertentu dalam hubungannya dengan orang lain.

\section{Sejarah Kajian Etnografi Komunikasi}

Etnografi komunikasi adalah suatu kajian mengenai pola-pola komunikasi sebuah komunitas budaya. Secara makro kajian ini adalah bagian dari etnografi.

Etnografi komunikasi (ethnography of communication) merupakan pengembangan dari Etnografi berbicara (Ethnography of speaking), yang dikemukakan oleh Dell Hymes pada tahun 1962 (Ibrahim, 1994:v). Pengkajian etnografi komunikasi ditujukan pada kajian peranan bahasa dalam perilaku komunikatif suatu masyarakat, yaitu mengenai cara-cara bagaimana bahasa dipergunakan dalam masyarakat yang berbedabeda kebudayaanya.

Thomas R. Lindlof dan Bryan C. Taylor, dalam bukunya Qualitative Communicatin Research Methods, menyatakan "Ethnography of Communication (EOC) conceptualizes communication as a continous flow of information, rather than as segmented exchanges message." (Lindlof \& Taylor, 2002:44). Dalam pernyataan tersebut, Lindlof dan taylor menegaskan bahwa konsep komunikasi dalam etnografi komunikasi merupakan arus informasi yang berkesinambungan, bukan sekadar pertukaran pesan antar komponennya semata.

Etnografi komunikasi berakar pada istilah bahasa dan interaksi sosial dalam aturan penelitian kualitatif komunikasi. Penelitiannya mengikuti tradisi psikologi, sosiologi, linguistik, dan antropologi. Etnografi komunikasi difokuskan pada kode-kode budaya dan ritual-ritual.

Dalam artikel pertamanya, Hymes (1962) menjelaskan bahwa etnografi berbicara menyangkut tentang situasi-situasi dan penggunaan pola dan fungsi berbicara sebagai suatu aktivitas tersendiri (Hymes 1962/1968:101, dalam Ibrahim,1994:260). Kajian etnografi 
komunikasi yang dimulai oleh Hymes, sejak saat itu memacu sejumlah studi mengenai pola-pola komunikasi dalam berbagai masyarakat di seluruh dunia untuk dikembangkan.

Etnografi komunikasi, sebagai suatu kajian telah dikenal sejak penerbitan salah satu edisi American Antrhopologist dengan judul ethnography of commmunication (http:// www.dea.unibo.it/narduzo/sssup/ethno2.pdf.). Dalam perkembangannya, etnografi komunikasi digambarkan dengan jelas mengenai perhatian masyarakat dengan analisis interaksional dan identitas peran dalam mengombinasikan berbagai minat dan orientasi teoretis. Etnografi komunikasi telah menjadi suatu disiplin ilmu yang menunjukan suatu pengolahan informasi dalam strukturisasi perilaku komunikatif, dan perannya dalam kehidupan masyarakat (Saville-Troike, http:// www.dea.unibo.it /narduzo/sssup/ ethno2.pdf.). Lebih lanjut Saville-Troike menjelaskan:

Etnografi komunikasi mengambil bahasa sebagai bentuk kebudayaan dalam situasi sosial yang pertama dan paling penting, sementara juga menyadari perlunya menganalisis kode itu sendiri dan proses kognitif penutur dan pendengarnya. Menerima ruang lingkup yang lebih kecil untuk deskripsi linguistik itu, dan menolak adanya kemungkinan memahami bagaimana bahasa hidup dalam pikiran dan pada lidah para pemakainya (Saville-Troike, 1982:3-4, dalam Ibrahim, 1994:305).

Etnografi komunikasi menjadi kontroversial sejak semula. Salah satu kontroversi adalah tentang hubungannya dengan bidang linguistik sebagai suatu keseluruhan. Dell Hymes sebagai pencetus teori etnografi komunikasi, memberikan batasan tegas antara lingusitik dan komunikasi. Kajian etnografi komunikasi bukanlah kajian lingusitik namun merupakan kajian etnografi, serta bukan pula mengenai bahasa, tetapi mengenai komunikasi. “... it is not linguistics, but ethnography, not language, but communication, which must provide the frame of reference within which the place of language in culture and society is to be assessed' (.. ini bukan linguistik, tapi etnografi, bukan bahasa, tapi komunikasi, yang harus melengkapi kerangka pikir secara mendalam tempat bahasa dalam kebudayaan dan masyarakat ditetapkan) (Hymes, 1971:4, dalam Alwasilah, 2003:61)

Lindlof dan Taylor (2002:44) mengemukakan tentang kefleksibelan teori etnografi komunikasi. Telah banyak ahli yang menerapkan konsep etnografi komunikasi ini, selain pada pengkajian linguistik, seperti pengkajian tentang talk show di televisi (Carbaugh, 1993); fotografi keluarga (Musello, 1980), dan ritual keanggotaan (Braitwhite, 1997) (Lindlof \& Taylor, 2002:44).

\section{Pengertian tentang Etnografi}

Istilah etnografi berasal dari kata ethno (bangsa) dan graphy (menguraikan), jadi etnografi yang dimaksud adalah usaha untuk menguraikan kebudayaan atau aspek-aspek kebudayaan (Moleong, 1990:13). Etnografi merupakan suatu bangunan pengetahuan yang meliputi teknik penelitian, teori etnografi, dan berbagai macam deskripsi kebudayaan (Spradley, 1997:12).

Etnografi lazimnya bertujuan menguraikan suatu budaya secara meyeluruh, yakni semua aspek budaya, baik yang material seperti artefak budaya (alat-alat, pakaian, bangunan, dan sebagainya) dan yang bersifat abstrak, seperti pengalaman, kpercayaan, norma dan sistem nilai kelompok yang diteliti. Uraian tebal (thick description) merupakan ciri utama etnografi (Mulyana, 2003:161).

Menurut Dr. Amri Marzali, ditinjau secara harfiah, etnografi berarti tulisan atau laporan tentang suku bangsa, yang ditulis oleh seorang antropolog atas hasil penelitian lapangan selama sekian bulan atau sekian tahun (Spradley, 1997:xv). Etnografi merupakan kegiatan penulis untuk memahami cara orang-orang berinteraksi dan bekerja sama melalui fenomena teramati kehidupan sehari-hari. Dengan kata lain, penulis terlibat langsung dengan objek penulisan dalam melakukan pemaknaan atau interpretasi terhadap penulisan yang dilakukan.

James P. Spradley(1997:12), mengungkapkan, etnografi adalah suatu kebudayaan yang mempelajari kebudayaan lain. Inti dari etnografi 
Tabel 1

Tipe-Tipe Penelitian Antropologi Budaya

\begin{tabular}{|l|l|l|l|}
\hline & Masyarakat Tunggal & Wilayah & Sampel Organisasi \\
\hline Nonhistoris & Etnografi & Perbandingan terkontrol & Penelitian Silang-budaya \\
\hline Historis & Etnohistoris & Perbandingan terkontrol & Penelitian Silang-sejarah \\
\hline
\end{tabular}

adalah upaya memperhatikan makna tindakan dari kejadian yang menimpa orang yang ingin kita pahami. Beberapa makna ini terekspresikan secara langsung dalam bahasa; dan banyak yang diterima dan disampaikan hanya secara tidak langsung melalui kata dan perbuatan (Spradley, 1997:5).

Menurut Bronislaw Malinowski (dalam Spradley, 1997:3), tujuan etnografi adalah memahami sudut pandang penduduk asli, hubungannya dengan kehidupan, untuk mendapatkan pandangannya mengenai dunianya. Oleh karena itu, penelitian etnografi melibatkan aktivitas belajar mengenai dunia orang yang telah belajar melihat, mendengar, berbicara, berpikir, dan bertindak dengan cara-cara yang berbeda. Tidak hanya mempelajari masyarakat, lebih dari itu etnografi berarti belajar dari masyarakat.

\section{Etnografi sebagai Tipe Penelitian}

Etnografi dalam perspektif antropologi budaya merupakan suatu tipe penelitian yang dilakukan pada masyarakat tunggal, dengan analisisnya bersifat nonhistoris. Hal ini seperti dikemukakan Ember dan Ember dalam Sri Rejeki (2004).

Sebagai salah satu tipe penelitian dalam antropologi budaya, maka etnografi memiliki struktur, konsep-konsep, dan prinsip-prinsip yang diambil dari induknya (Sarantakos '93 dalam Sri Rejeki, 2004). Guna menghasilkan sebuah bentuk penelitian etnografis, seorang ernografer perlu melakukan pemetaan, yakni pemetaan atas wacana sosial. Dalam kerangka ini, Griffin (2003) dalam Sri Rejeki (2004) memberikan analoginya yang menarik, yakni bahwa peneliti etnografi akan bekerja sebagai seorang ahli geografi yang melakukan pemetaan tentang budaya suatu masyarakat. Untuk melakukan pemetaan itu, peneliti harus berlamalama tinggal di suatu tempat, berbicara dengan orang-orang yang tinggal di situ (in site) dan mengamati kebiasaan mereka.

Prinsip-prinsip pemetaannya sendiri bersifat holistik, kontekstual, berpandangan emik, mengakui realitas ganda, dan nonjudgmental orientation (orientasi yang tidak menilai). Fetterman (1989) dalam Sri Rejeki 92004) mengemukakan bahwa prinsip holistik terkait dengan asumsi yang menyatakan peneliti harus memperoleh gambaran yang lengkap (multi-faceted) dan komprehensif tentang komunitas yang diteliti. Peneliti perlu mengandaikan bahwa objek yang diteliti merupakan the part of the whole. Dengan demikian, peneliti perlu melihat kaitan-kaitan dalam budaya dan komunitas itu sebanyak mungkin. Gambaran ini bisa mencakup sejarah, agama, politik, ekonomi, dan lingkungan dari komunitas itu. Prinsip ini pun mensyaratkan teknik-teknik pengumpulan data yang mampu menjamin jangkauan peneliti atas seluruh kehidupan sosial. Teknik-teknik tersebut mencakup observasi partisipatif, in-depth interview, focus group discussion (FGD), dan life history. 
Pengontektualisasian berarti menempatkan inkuiri ke dalam suatu pengamatan yang lebih besar/ luas. Sementara prinsip emik, mengharuskan peneliti mengumpulkan dan menganalisis data dengan bertolak dari pandangan masyarakat setempat the native's point of view. Sedangkan prinsip nonjudgmental merupakan prinsip tidak menyatakan pendapat atas realitas yang diamati. Prinsip ini mendorong peneliti untuk melakukan eksplorasi tanpa menilai, di mana penilaian itu justru berisiko menghasilkan pemahaman yang tak sesuai.

Konsep lain yang inheren dalam ernografi adalah konsep budaya dan in-depth studies. Budaya merupakan konsep sentral dari etnografi. Budaya dipelajari sebagai sebuah kesatuan. Entitas budaya adalah sistem yang digunakan bersama oleh komunitas. Para anggota budaya ini mempelajari unsur-unsur dan konfigurasinya melalui interaksi serta dengan cara hidup dalam budaya itu. Guna mencapai hal itu, kerja ernografer tak dapat dilakukan di tataran permukaan, ia perlu melakukan in-depth studies. Cara ini menjadi jaminan kedalaman penghayatan atas pengalaman budaya yang dimiliki oleh subjek penelitian.

\section{Etnografi sebagai Metode Penelitian}

Sri Rejeki (2004) mengemukakan bahwa etnografi selain dapat dipandang sebagai sebuah tipe penelitian, juga dapat diperlakukan sebagai metode penelitian. Jika dilihat dalam konteks yang lebih besar, maka etnografi adalah sebuah metode penelitian yang berpayung di bawah paradigma konstruktivisme dan di dalam perspektif teoretik interpretivisme.

Etnografi sebagai sebuah metode yang berada di bawah perspektif teoretik interpretivisme merupakan suatu cara bagi peneliti untuk mendekati objek penelitian dalam kerangka interpretivisme. Adapun landasan pemikiran adalah bahwa realitas sosial diciptakan dan dilestarikan melalui pengalaman subjektif dan intersubjektif dari para pelaku sosial. Para pelaku sosial ini dipandang aktif sebagai interpreter-interpreter yang dapat menginterpretasikan aktivitas simbolik mereka. Aktivitas-aktivitas simbolik itu seperti permainan bahasa, ritual, ritual verbal, metafora-metafora, dan drama-drama sosial. Makna-makna yang dikejar adalah makna subjektif dan makna konsensus. Makna subjektif adalah makna yang mengacu pada interpretasi individual, sedangkan makna konsensus merupakan makna yang diinterpretasikan secara kolektif. Makna subjektif dikontruksi melalui proses-proses kognitif manusia. Sementara, makna konsensus dikontruksi melalui proses-proses interaksi sosial. Kedua makna tersebut pada hakikatnya merupakan makna-makna yang menunjukkan realitas sosial. Asumsinya adalah bahwa realitas secara sosial dikonstruksi melalui kata, simbol, dan perilaku dari para anggotanya. Kata, simbol, dan perilaku ini

Tabel 2

Perspektif Teoretik dan Metode Penelitian dalam Konstruktivisme

\begin{tabular}{|l|ll|}
\hline \multicolumn{1}{|c|}{ Perspektif Teoretik } & \multicolumn{1}{c|}{ Metode Penelitian } \\
\hline & & \\
Interpretivisme & 1. Etnografi \\
1. Interaksionisme Simbolik & 2. Fenomenologis \\
2. Fenomenologi & 3. Grounded Research \\
3. Hermeneutik & 4. Heuristic inquiry \\
\hline
\end{tabular}


merupakan sesuatu yang bermakna. Pemahaman atasnya akan melahirkan pemahaman atas rutinitas sehari-hari dalam praktik-praktik subjek penelitian.

\section{Metode Etnografi Komunikasi}

Metode etnografi komunikasi merupakan metode etnografi yang diterapkan untuk melihat pola-pola komunikasi kelompok sosial.

Ada empat asumsi etnografi komunikasi. Pertama, para anggota budaya akan menciptakan makna yang digunakan bersama. Mereka menggunakan kode-kode yang memiliki derajat pemahaman yang sama. Kedua, para komunikator dalam sebuah komunitas budaya harus mengordinasikan tindakan-tindakannya. Oleh karena itu, di dalam komunitas itu akan terdapat aturan atau sistem dalam berkomunikasi. Ketiga, makna dan tindakan bersifat spesifik dalam sebuah komunitas, sehingga antara komunitas yang satu dan lainnya akan memiliki perbedaan dalam hal makna dan tindakan tersebut. Keempat, selain memiliki kekhususan dalam hal makna dan tindakan, setiap komunitas juga memiliki kekhususan dalam hal cara memahami kode-kode makna dan tindakan.

Dell Hymes (Ibrahim,2004) membuat kategori yang dapat digunakan untuk membandingkan budaya-budaya yang berbeda. Kategori-kategori tersebut adalah:

(1) Ways of speaking. Dalam kategori ini, peneliti dapat melihat pola-pola komunikasi komunitas.

(2) Ideal of the fluent speaker. Dalam kategori ini, peneliti dapat melihat sesuatu yang menunjukkan hal-hal yang pantas dicontoh/ dilakukan oleh seorang komunikator.

(3) Speech community. Dalam kategori ini, peneliti dapat melihat komunitas ujaran itu sendiri, berikut batas-batasnya.

(4) Speech situation. Dalam kategori ini, peneliti dapat melihat situasi ketika sebuah bentuk ujaran dipandang sesuai dengan komunitasnya.

(5) Speech event. Dalam kategori ini, peneliti dapat melihat peristiwa-peristiwa ujaran yang dipertimbangkan merupakan bentuk komunikasi yang layak bagi para anggota komunitas budaya.

(6) Speech art. Dalam kategori ini, peneliti dapat melihat seperangkat perilaku khusus yang dianggap komunikasi dalam sebuah peristiwa ujaran.

(7) Component of speech acts. Dalam kategori ini, peneliti dapat melihat komponen tindak ujaran.

(8) The rules of speking in the community. Dalam kategori ini, peneliti dapat melihat garis-garis pedoman yang menjadi sarana penilaian perilaku komunikatif.

(9) The function of speech in the community. Dalam kategori ini, peneliti dapat melihat fungsi komunikasi dalam sebuah komunitas. Dalam kerangka ini, menyangkut kepercayaan bahwa sebuah tindakan ujaran dapat menyelesaikan masalah yang terjadi dalam komunitas budaya.

Menyimak hal tersebut, etnografi komunikasi memiliki kemampuan untuk melihat variabilitas komunikasi. Selain itu, etnografi komunikasi juga memiliki kelebihan untuk (1) mengungkapkan jenis identitas yang digunakan bersama oleh anggota komunitas budaya. Identitas tersebut diciptakan oleh komunikasi dalam sebuah komunitas budaya. Identitas itu sendiri pada hakikatnya merupakan perasaan anggota budaya tentang diri mereka sebagai komunitas. Dengan kata lain, identitas merupakan seperangkat kualitas bersama yang digunakan para anggota budaya dalam mengidentifikasikan diri mereka sebagai komunitas. (2) Mengungkapkan makna kinerja publik yang digunakan bersama dalam komunitas. (3) Mengungkapkan kontradiksi atau paradoksparadoks yang terdapat dalam sebuah komunitas budaya.

Untuk kepentingan mengungkap aspek-aspek tersebut, ada tiga pertanyaan yang harus dikemukakan, yaitu pertanyaan tentang norma, pertanyaan tentang bentuk, dan pertanyaan tentang kode-kode budaya. Pertanyaan tentang norma menyangkut pencarian cara-cara komunikasi yang digunakan untuk memantapkan seperangkat patokan dan gagasan tentang benar dan salah yang memengaruhi pola-pola 
komunikasi. Pertanyaan bentuk terkait dengan jenis komunikasi yang digunakan dalam komunitas, yaitu menyangkut suatu perilaku yang dapat dikategorikan sebagai komunikasi. Selain itu juga menyangkut tentang cara pengorganisasian perilaku komunikasi tersebut. Pertanyaan tentang kode-kode budaya memberikan perhatian pada makna simbol dan perilaku yang digunakan sebagai komunikasi dalam komunitas budaya.

\section{Unit Analisis Etnografi Komunikasi}

Untuk mengkaji perilaku komunikatif dalam masyarakat tutur, diperlukan pengkajian unit-unit interaksi. Hymes (1972:58-59, dalam Ibrahim, 1994:266-267) mengemukakan bahwa nested hierarchy (hierarki lingkar) unit-unit yang disebut situasi tutur (speech situation), peristiwa tutur (speech event), dan tindak tutur (speech act) akan berguna. Dan, apa yang dia kemukakan sudah diterima secara luas. Dengan kata lain, tindak tutur merupakan bagian dari peristiwa tutur dan peristiwa tutur merupakan bagian dari situasi tutur.

Nested hierarchy yang diungkapkan oleh Hymes tersebut mendasari unit analisis yang penulis lakukan, yaitu mendeskripsikan interaksi yang terjadi dalam praktik-prakrtik komunikatif (communicative practices), yang terdiri dari: situasi komunikatif (communicative situation), peristiwa komunikatif (communicative event), dan tindak komunikatif (communicative act).

Situasi komunikatif (communicative situation) merupakan konteks terjadinya komunikasi, situasi bisa tetap sama walaupun lokasinya berubah, atau bisa berubah dalam lokasi yang sama apabila aktivitas-aktivitas yang berbeda berlangsung di tempat tersebut pada saat yang berbeda. Situasi yang sama bisa mempertahankan konfigurasi umum yang konsisten pada aktivitas dan ekologi yang sama di dalam komunikasi yang terjadi, meskipun terdapat perbedaan dalam jenis interaksi yang terjadi di sana (Ibrahim,1994:36).

Situasi komunikatifmerupakan perluasan dari situasi tutur. namun, situasi tutur tidaklah murni komunikatif; situasi ini bisa terdiri dari peristiwa komunikatif maupun peristiwa yang bukan komunikatif. Situasi bahasa tidak dengan sendirinya terpengaruh oleh kaidah-kaidah berbicara, tetapi bisa diacu dengan menggunakan kaidah-kaidah berbicara itu sebagai konteks.

Peristiwa komunikatif (communicative event) merupakan unit dasar untuk tujuan deskriptif. Sebuah peristiwa tertentu didefinisikan sebagai seluruh perangkat komponen yang utuh. Kerangka komponen yang dimaksud, Dell Hymes menyebutnya sebagai nemonic

Models yang diakronimkan dalam kata speaking, yang terdiri dari: setting/scene, participants, ends, act sequence, keys, instrumentalities, norms of interaction, genre. Berikut penjelasan ringkas mengenai komponen-komponen tersebut (Ibrahim, 1994:208-209):

(a) Setting, merupakan lokasi (tempat), waktu, musim dan aspek fisik situasi tersebut. Scene adalah abstrak dari situasi psikologis, definisi kebudayaan mengenai situasi tersebut;

(b) Participants, partisipan adalah pembicara, pendengar, atau yang lainnya, termasuk kategori sosial yang berhubungan dengannya;

(c) Ends, merupakan tujuan mengenai peristiwa secara umum dalam bentuk tujuan interaksi partisipan secara individual. Secara konvensional dikenal juga sebagai fungsi, dan diharapkan sebagai hasil akhir dari peristiwa yang terjadi;

(d) Act Sequence, disebut juga urutan tindak komunikatif atau tindak tutur, termasuk di dalamnya adalah message content (isi pesan), atau referensi denotatif level permukaaan; apa yang dikomunikasikan;

(e) Keys, mengacu pada cara atau spirit pelaksanaan tindak tutur, dan hal tersebut merupakan fokus referensi;

(f) Instrumentalities, merupakan bentuk pesan (message form). Termasuk di dalammya, saluran vokal dan nonvokal, serta hakikat kode yang digunakan;

(g) Norms of Interaction, merupakan norma-norma interaksi, termasuk di dalamnya pengetahuan umum, pengandaian kebudayaan yang relevan, atau pemahaman yang sama, yang memungkinkan adanya inferensi tertentu yang harus dibuat, apa yang harus dipahami secara 
harfiah, apa yang perlu diabaikan dan lain-lain;

(h) Genre, secara jelas didefiniskan sebagai tipe peristiwa. Genre mengacu pada kategorikategori seperti puisi, mitologi, peribahasa, ceramah, dan pesan-pesan komersial.

Unit analisis etnografi komunikasi yang terakhir, yang termasuk ke dalam lingkar hierarki Dell Hymes adalah tindak komunikatif (communicative act). Tindak komunikatif merupakan bagian dari peristiwa komunikatif. Tindak komunikatif pada umumnya bersifat koterminus ${ }^{1}$ dengan fungsi interaksi tunggal, seperti pernyataan referensial, permohonan, atau perintah, dan bisa bersifat verbal atau nonverbal. Dalam konteks komunikatif, bahkan diam pun merupakan tindak komunikatif konvensional (Ibrahim, 1994:38).

\section{Daftar Pustaka}

Alwasilah, A. Chaedar. 2003. Pokoknya Kualitatif: Dasar-Dasar Merancang dan Melakukan Penelitian Kualitatif. Jakarta: Dunia Pustaka Jaya dan Pusat Studi Sunda.

Ibrahim, Abd Syukur. 1994. Panduan Penelitian Etnografi Komunikasi. Surabaya: Usaha Nasional.
Koentjaraningrat. 1997. Manusia dan Kebudayaan di Indonesia. Jakarta: Djambatan.

Liliweri, Alo. 2003. Dasar-dasar Komunikasi Antarbudaya. Yogyakarta: Pustaka Pelajar.

Lindlof, Thomas R, dan Bryan C. Taylor. 2002. Qualitative Communication Research Methods. California: Sage Publication.

Moleong, J. Lexy. 2002. Metode Penelitian Kualitatif. Bandung: Remaja Rosdakarya.

Mulyana, Deddy. 2003. Metode Penelitian Kualitatif. Bandung: Remaja Rosdakarya.

dan Jalaluddin Rakhmat. 2003. Komunikasi Antarbudaya: Panduan Berkomunikasi dengan Orang-orang Berbeda Budaya. Bandung: Remaja Rosdakarya,

Van Peursen, C. A. 1989. Strategi Kebudayaan, Penerjemah: Dick Hartoko. 1989. Kanisius, Yogyakarta,

Spradley, James p. 1997. Metode Etnografi, Penerjemah: Misbah Zulfa Elizabeth, Tiara Wacana, Yogyakarta, 